\title{
Ki a tudós?
}

\section{A TUDOMÁNY: ÖNVÉDELMÜNK}

\section{SCIENCE: OUR SELF DEFENCE}

\author{
Vámos Tibor \\ az MTA rendes tagja \\ vamos@sztaki.mta.hu
}

\section{A TUDÓS}

Fogalmaink megfigyelések és meggondolások alapján összeálló eszközök. Mind a három meghatározó, a megfigyelés, a meggondolás és az eszköz egyenként is elárulja az életben nélkülözhetetlen fontosságot és az ellenőrzés állandó, lehetőleg tudatos szükségességét.

Így vagyunk a 'tudós' szóval és fogalommal is, megterhelve azzal, hogy a szó használatos jelzőként, embertípus megjelöléseként és foglalkozási ágként is.

Miben tudós, milyen tudós?, következik a szó hallatán, mintegy önmüködően. A Magyarországon is müködött Regiomontanus (königsbergi Johannes Müller) a maga korának egyik legnagyobb és legszélesebb látókörü tudósa volt, elsősorban a csillagászatban és a matematikában, de főként az asztronómia hamis tudománya ködeiben, úttörő geometriai táblázatai ma egy kisiskolás gyermek számára sem magas tudományok. A mai tudományos és gyakorlati életben tömegével dolgoznak magasan képesített okos és szorgalmas emberek, akik egy részletismeret kibontásával és esetleges felhasználásával nélkülözhetetlen munkát végeznek, de akármelyik nagynak elismert példakép mértékében csak megértő jóindulattal tekinthetők tudósoknak.

A Regiomontanus-utalás szemléltető példa a tudomány és áltudomány egyik viszonylatára. A másik a tudatos szélhámos, aki tudja, hogy csal, de ebből kitűnően megél, és néha még igazinak tűnő eredményre is jut, mint az alkímia gyakorlóinak többsége. Közülük sokan valóban őszintén hittek hókuszpókuszaikban. Egy másik képlet Semmelweis Ignácé, aki nem tudhatta, hogy mikrobákat és egyéb bomlási méreganyagokat távolít el, de Louis Pasteur előtt ráérzett valamire, amivel életeket mentett. Pasteur elismert tudós lett, Semmelweis hányatott életútját ismerjük.

Akkor miért harcolunk az áltudományok és képviselöik ellen? Van tudományos diszciplínákon kívüli kritériumunk: az állítások reprodukálásban el- 
lenőrizhető megmérése és főleg a hasznosság és károkozás vizsgálata. Ilyen utóbbi a védőoltások elleni érvelés vagy a bevált és ígéretes gyógymódok elutasítása. Ide sorolhatjuk a rosszindulatú érzelmek keltését, üzleti és halmai célú befolyásolást.

Egyébként legyünk óvatosak jelzőink és minősítéseink használatában.

\section{VÁLTOZÁSOK A TUDOMÁNY KÖRÜL}

Támadják a Tudományt, azaz a világ megismerésének hivatását. Olyan régi ez a folyamat, mint maga a hivatás, de manapság a megszokott források bővültek, a szereplők nemcsak az aktuális tévhitek és zavaros személyiségek, hanem a társadalom befolyásos körei is. A változás oka a tudomány önálló gazdasági és társadalmi helyzete. A megismerési tevékenység minden korábbi területen túl is kiszélesedett a tudományunk által létrehozott mesterséges világunk egészére.

A nehezen határolható tudománydefiníciók helyett a következők adnak körvonalazható nézeteket.

Az embert tudománya emelte ki az állatvilágból. Demonstrációként szolgálhatna az az installáció, amely az őskortól napjainkig, korszakonként bemutatná, hogyan módosult az ember és léte a tudománya eredményeként. Ez a demonstráció az európai tudományt és életformát követi, és azokat a más kultúrákat, amelyek más, esetleg hasonló gyökerek mellett is, napjainkra ezt az utat sajátították el. A kirándulás után feltehetjük közönségünknek a kérdést: melyik korszakban szeretnének élni, vállalva az akkori élettartamokat, gyermekhalandóságokat, rendszeres éhínségeket, fázást, zsúfolt lakásviszonyokat, utazási kényelmetlenségeket, testi és lelki gyötrelmeket?

Valamennyi állomáson voltak elkülönült szakértők: írástudók, orvosok, különleges felkészültségü mesteremberek, de az utolsó évszázadok folyamán két tényező gerjesztette egy anyagi hátterében és felkészültségében elkülönült szektor növekedését: az egyik a feladatok és megoldások bonyolultabbá válása, a másik, az eredmények tömegesedése. Ez a két tényező kapcsolta össze és választotta szét a tudományt, annak művelőit és a társadalom többi, egyre inkább érdekeltté vált rétegeit.

\section{BONYOLULTSÁG ÉS KÖZÉRTHETŐSÉG}

A bonyolultság a közérthetőség egyre erősebb gátja. Olyan jellegü és mértékü, ami az egyes szaktudományokon belül is elhatárol, más alapokat, más nyelvet és más figyelemfókuszálást követel. Ugyanakkor elkerülhetetlen, hiszen éppen a tudományos kutatás, a megismerés előrehaladása tárta fel azokat a kimerít- 
hetetlen mélységeket, amelyek a jelenségek valódi hátterében müködnek. A korábbi világnézetek olyan hiteket sugalltak, amelyek szerint a világ egységes eszközökkel leírható, és így megérthetővé válik. Az utolsó ilyen hit a Bertrand Russell és David Hilbert nevével jelzett remény, a világ jelenségeinek egységes matematikai, logikai módszerekkel megközelíthető általános leírása volt. Ezzel az, a már a bonyolultság magasságait ostromló elképzelés, hogy ez az összefoglaló látvány, így a Maxwell-egyenleteké az elektromágnesesség teljességéről és a Hamilton-egyenleteké az egyensúlyok és változások energia jellegü átfogásáról az Egész hiteles magyarázata felé mutatnak, és megfelelő felvilágosító-oktató munkával az ezekhez füződő világkép a szélesebb emberi közösségek számára is beláthatóvá válik. A huszadik század elejére, a kvantumelmélet, az általános relativitáselmélet, a logikák sokfajtasága, ebben a gödeli eredmények és a társadalmi mozgások fenyegető irracionalizmusa a világos megmagyarázhatóság reményeit megdöntötték. Szembekerültünk a világ végtelen arcú sokféleségével és azzal a felismeréssel, hogy az egyszerüsítő, összefoglaló tudományos eszközök, ebben a matematika is, nem közelíthetik meg ezt a valóságot. A részeredmények és speciális eszközök tömege ugyanakkor eddig beláthatatlan, gyakorlatban is müködő közelítéseket szolgáltatott a mindennapok számára is. Így a bonyolultság nem a tudományos közösségek misztikuma, hanem a mindennapossá vált világunk szükségszerü probléma- és eszközrendszerbeli valóságává lett.

\section{TÖMEGESEDÉS}

Az utolsó mondat félelmetessége a siker tömegesedésével párosult. A tömegesedés a tudományos, kísérleti eredmények hatalmas megerősödésének továbblépése, újabb termékeny invenciót, számos korábbi tudományos eredmény szintézisét, új technológiák létrehozását és bevezetését, hatalmas gazdasági koncentrációk születését gerjesztette. A modern értelemben használt 'innováció' fogalom ebben testesült meg. A szellemi kiválasztottak és anyagiakban gazdag rétegek korábbi, privilegizált tulajdona, életformája és lehetőségei ennek révén váltak általánossá, először a világ gazdagabb régióiban, de terjedt tovább a korábban viszonylag elmaradottabb területeken is. Így váltak a bevezetőben felsorolt, mai haladás részeseivé.

A hova vissza rousseau-i kérdés az elsősorban európai jellegü világokban lett észszerütlen. Az európai jelleg is ennek a folyamatnak nyomán bővült megállíthatatlanul globális hatássá, még a legnagyobb, más kulturális hagyományú vidékeken is. Ez tette aktuálissá a humánus szerepideálok széles körü felmerülését, a régi kérdés megújulását: mi végre vagyunk a világban? 


\section{AZ ÁRNYÉKOK OLDALA}

Nem feledkezhetünk meg mindezek visszájáról, a tudomány és a kapcsolódó technikák felhasználásának borzalmairól, genocídiumokról, háborúkról, elnyomásokról, szellemi sivatagosodásokról. A tömegesedés és annak fö technikai eszközei, az információs technológiák felszínre szorították az embercsoportok együttmüködésének és irányításának ősi alapproblémáit.

Ide kacsolódik a tudomány és a természeti környezet viszonya. Az ember majdnem a történelem kezdetei óta rombol, gondoljunk csak a területeket sivataggá változtató erdőirtásokra, lelegelt vidékekre, a nyomor túlnépesedéseire vagy később, a szénkorszak légszennyezésére. A tudomány tudatosított, és létrehozta a bölcsebb kompromisszumok, az élhető világ reményének eszközeit.

\section{TÁJÉKOZÓDÁSI KAPASZKODÓK}

Mindezekről gondolkodva jogos a kétely: hol vannak a tudomány, a technika megbízhatósági határai, mit és hogyan lehet elfogadnunk egy ilyen, a közembereket egyre általánosabban befolyásoló közegből s annak hatásaiból?

Az után a tudományszemléleti fordulat után, amit a mindent kiszámító és rendszerbe foglaló tudományhittel szemben a mai gondolkodásmódunk sugall, azt kell mondanunk, hogy abszolút mértékeink nincsenek, és nagy valószínűséggel nem is lesznek, vagy, ahogy Esterházy Péter fogalmazza egy Jorge Luis Borgestől vett idézettel: Egyébként a fökérdés megoldhatatlan: a végtelennek akárcsak részleges felsorolása.

Van azonban az esetek többségében jól hasznosítható osztályozó elvünk, amit elsősorban az orvostudományból kölcsönzünk. Ez a következtetések reprodukálásának kritériuma és ehhez kapcsolódva az adott válasz, módszer, elgondolás eredményességének vizsgálata. A bizonytalanságok itt is feltűnőek, hiszen mindig kérdéses az azonos körülmények reprodukálásának követelménye és hasonlóan az eredményességek szempontjainak sokszínüsége. A mostani koronavírus járvány kapcsán mindezzel találkozunk.

Sokkal nehezebben kezelhetők a kevésbé feldolgozott, kisebb közvetlen aktualitású ismeretterületek, így a társadalomtudományok, de ez alól nem kivétel a konkrétabban kezelt müszaki szféra. Egy-egy gyártmány ismertetője is számos előnyös és ugyanakkor óvatosságra intő jellemzőt sorol fel.

Miként az idézett és megszámlálhatatlan egyéb példa mutatja, ismereteink és e mögött ott áll a tudomány, a valóság, ami végtelen arculatával nem szorítható teljesen és véglegesen kemény formulakeretekbe. Ez mutat rá a probléma izgalmas, életünk minden jelenségét befolyásoló sajátosságára. Élünk, müködünk, minden pillanatunkban ismeretekre támaszkodunk, olyanokra, amelyek kétes szilárdságát is ugyanilyen tényként kell tudomásul vennünk. 


\section{A TUDOMÁNY MINT A TERMÉSZET, AMIT LEKÉPEZNI IGYEKSZIK}

Van ilyen: ez a természet, a maga élő, működő, állandóan változó valósága. Amivel ebben a látszólagos és valóságos kuszaságban mégis némi sikerrel tájékozódunk, az a tudományunk, annak nyitottságával és pillanatnyi tudatállapotunk eddig sikeres biztonságával.

Az eddig az emberiség eddigi útjára vonatkozik, annak neumanni, optimista következtetésével:

„Az az egyetlen szilárd tény, hogy a nehézségek a hasznos és építő, de ugyanakkor veszedelmes fejlődésnek tulajdoníthatók. Alkalmazkodni tudunk-e a szükséges gyorsasággal? A legtöbb reménnyel az a válasz bíztat, hogy az emberi nem már kiállt hasonló próbákat és úgy látszik, veleszületett képessége van arra, hogy változó mennyiségü baj után mégis felülkerekedjék. Előre kész receptet kérni nem lenne ésszerü. Csak a szükséges emberi tulajdonságokat határozhatjuk meg: türelem, rugalmasság, intelligencia." 1

A metaforák és irányelvek adnak-e eligazítást az orvoslás gyakorlatának hasonlóan ősi kérdésére, az itt felvetett nil nocere, az ártalmasság problémájához? Talán az ellentettek felhasználásával. A reprodukálhatatlanság és az eredménytelenség, illetőleg káros eredmény bizonyításával, a neumanni felsorolást cáfoló tulajdonságokkal, a természetből kapott útmutatással, a sokfajtaságon alapuló evolúciós türelemmel, rugalmassággal és intelligenciával.

Az így fejlődő Tudomány szerepéről is az ősi tanulságot idézhetjük, Menenius Agrippa meséjét a test önálló és egymást nem nélkülöző szerepéről, esetünkben az emberiség agyáról, azzal a megjegyzéssel, hogy ezeknek a szerepeknek a viszonyai is módosulnak, ahogy az az evolúció évmilliói és ezrei alatt történt: ez a testrész lett a legnagyobb és legdöntőbb.

A természethez hasonlóan a másik hatalmas emberformálóval, a mủvészettel együtt, ez a kultúra maga. Örizzük és ápoljuk bölcsen, fennmaradásunk érdekében!

\footnotetext{
${ }^{1}$ Fordította Augusztinovics Mária.
} 